\title{
Found: a missing breeding ground for endangered western North Pacific humpback whales in the Mariana Archipelago
}

\author{
Marie C. Hill ${ }^{1,2, *}$, Amanda L. Bradford ${ }^{2}$, Debbie Steel ${ }^{3}$, C. Scott Baker ${ }^{3}$, \\ Allan D. Ligon ${ }^{4}$, Adam C. $\ddot{U}^{5}$, Jo Marie V. Acebes ${ }^{6}$, Olga A. Filatova ${ }^{7}$, Siri Hakala ${ }^{2}$, \\ Nozomi Kobayashi ${ }^{8}$, Yukari Morimoto ${ }^{9}$, Haruna Okabe ${ }^{8}$, Ryosuke Okamoto ${ }^{10}$, \\ Julie Rivers ${ }^{11}$, Takayuki Sato ${ }^{9}$, Olga V. Titova ${ }^{12}$, Robert K. Uyeyama ${ }^{13}$, Erin M. Oleson ${ }^{2}$ \\ ${ }^{1}$ Joint Institute for Marine and Atmospheric Research, Research Corporation of the University of Hawai'i, Honolulu, HI 96822, USA \\ ${ }^{2}$ Pacific Islands Fisheries Science Center, NMFS, NOAA, Honolulu, HI 96818, USA \\ ${ }^{3}$ Marine Mammal Institute, Oregon State University, Newport, OR 97365, USA \\ ${ }^{4}$ Erin, TN 37061, USA \\ ${ }^{5}$ Maple Falls, WA 98266, USA \\ ${ }^{6}$ BALYENA.ORG, Barangay Pangdan, Jagna, Bohol 6308, Philippines \\ ${ }^{7}$ Faculty of Biology, Moscow State University, Moscow 119992, Russia \\ ${ }^{8}$ Okinawa Churashima Research Center, Okinawa Churashima Foundation, 888 Ishikawa, Motobu-cho, Okinawa 905-0206, Japan \\ ${ }^{9}$ Ogasawara Marine Center, Everlasting Nature of Asia, Byoubudani Chichi-jima, Ogasawara-mura, Tokyo 100-2101, Japan \\ ${ }^{10}$ Ogasawara Whale Watching Association, Chichi-jima, Ogasawara-mura, Tokyo 100-2101, Japan \\ ${ }^{11}$ Commander US Navy Forces Europe/Africa, US Sixth Fleet, Naples, Italy \\ ${ }^{12}$ Kamchatka Branch of Pacific Institute of Geography FEB RAS, Petropavlovsk-Kamchatsky, 683024, Russia \\ ${ }^{13}$ Naval Facilities Engineering Command Pacific, Pearl Harbor, HI 96860, USA
}

ABSTRACT: Humpback whales Megaptera novaeangliae that breed in the western North Pacific (WNP) are listed as endangered under the US Endangered Species Act. Previous research in the WNP concluded that the full extent of humpback whale breeding areas is unknown. Recovering this endangered population requires identifying all associated breeding grounds and potential threats in those locations. Prior to 2015, humpback whales were known to occur in the Mariana Archipelago (within the WNP), but their population identity and habitat use there were unknown. To determine the population identity of humpback whales in the Mariana Archipelago and whether the area serves as a breeding ground for these whales, small-boat photo-identification and biopsy sampling surveys were conducted in the southern portion of the archipelago during February and March 2015-2018. A total of 14 mother-calf pairs and 27 other non-calf whales were encountered. Seven non-calves were re-sighted in multiple years, including 4 females associated with calves in one or more years. Competitive behavior was observed in multiple years. Comparisons with other North Pacific humpback whale catalogs resulted in matches to breeding (Japan and Philippines) and feeding (Russia) grounds in the WNP. DNA profiling of 28 biopsy samples identified 24 individuals (14 females, 10 males) representing 7 mitochondrial DNA haplotypes. The haplotype frequencies from the Mariana Archipelago showed the greatest identity with the Ogasawara breeding ground and Commander Islands feeding ground in the WNP. This study establishes the Mariana Archipelago as a breeding area for endangered WNP humpback whales, which should be considered in ongoing research and conservation efforts.

KEY WORDS: Humpback whales - Mariana Archipelago · Breeding ground · Photo-identification · Genetics 


\section{INTRODUCTION}

Humpback whales Megaptera novaeangliae live in all major oceans worldwide and migrate seasonally between summer feeding areas in cold high latitude waters and winter breeding areas in lower latitude tropical and subtropical waters. Humpback whales were initially listed globally as endangered under the US Endangered Species Act until 2016, when they were separated into 14 distinct population segments (NOAA 2016). While several populations were delisted, the population that breeds in the western North Pacific (WNP) remains listed as endangered.

During 2004-2006, a large-scale international collaborative study was conducted on humpback whales throughout the North Pacific Ocean, called the 'Structure of Populations, Levels of Abundance, and Status of Humpbacks' (SPLASH) (Barlow et al. 2011, Baker et al. 2013). Photo-identification and biopsy sampling of individual whales took place on all known winter breeding areas during 3 seasons (2004, 2005, 2006) and all known summer feeding areas during 2 seasons $(2004,2005)$ (Fig. 1). At the time, known humpback whale breeding areas within the WNP included the Ryukyu Islands (e.g. Okinawa) and the Ogasawara (Bonin) Islands of Japan, as well as the northern Philippines. The SPLASH study determined that the Kamchatka Peninsula and the Commander Islands in the Russian Far East may be a primary feeding area for whales from WNP breeding areas (Barlow et al. 2011, Silberg et al. 2013), but movements of some individuals between Ogasawara, Okinawa, and the Philippines and feeding areas in the Aleutian Islands, Bering Sea, and Gulf of Alaska have been documented with discovery tag recaptures and photo-identifications (Omura \& Ohsumi 1964, Nishiwaki 1966, Ohsumi \& Masaki 1975, Darling et al. 1996, Calambokidis et al. 2001, Witteveen et al. 2004, Barlow et al. 2011). Movements of humpback whales between winter breeding areas in the North Pacific are considered rare (Bettridge et al. 2015), but a small number of individuals have been documented moving between breeding areas within the same year (Philippines, Okinawa, and Ogasawara) (Calambokidis et al. 2001, Acebes et al. 2007) and between years (Ogasawara-Hawai'i, Ogasawara-Okinawa, Philippines-Hawai'i, Philippines-Ogasawara, Philippines-Okinawa) (Darling \& Cerchio 1993, Salden et al. 1999, Calambokidis et al. 2001, Acebes et al. 2007).

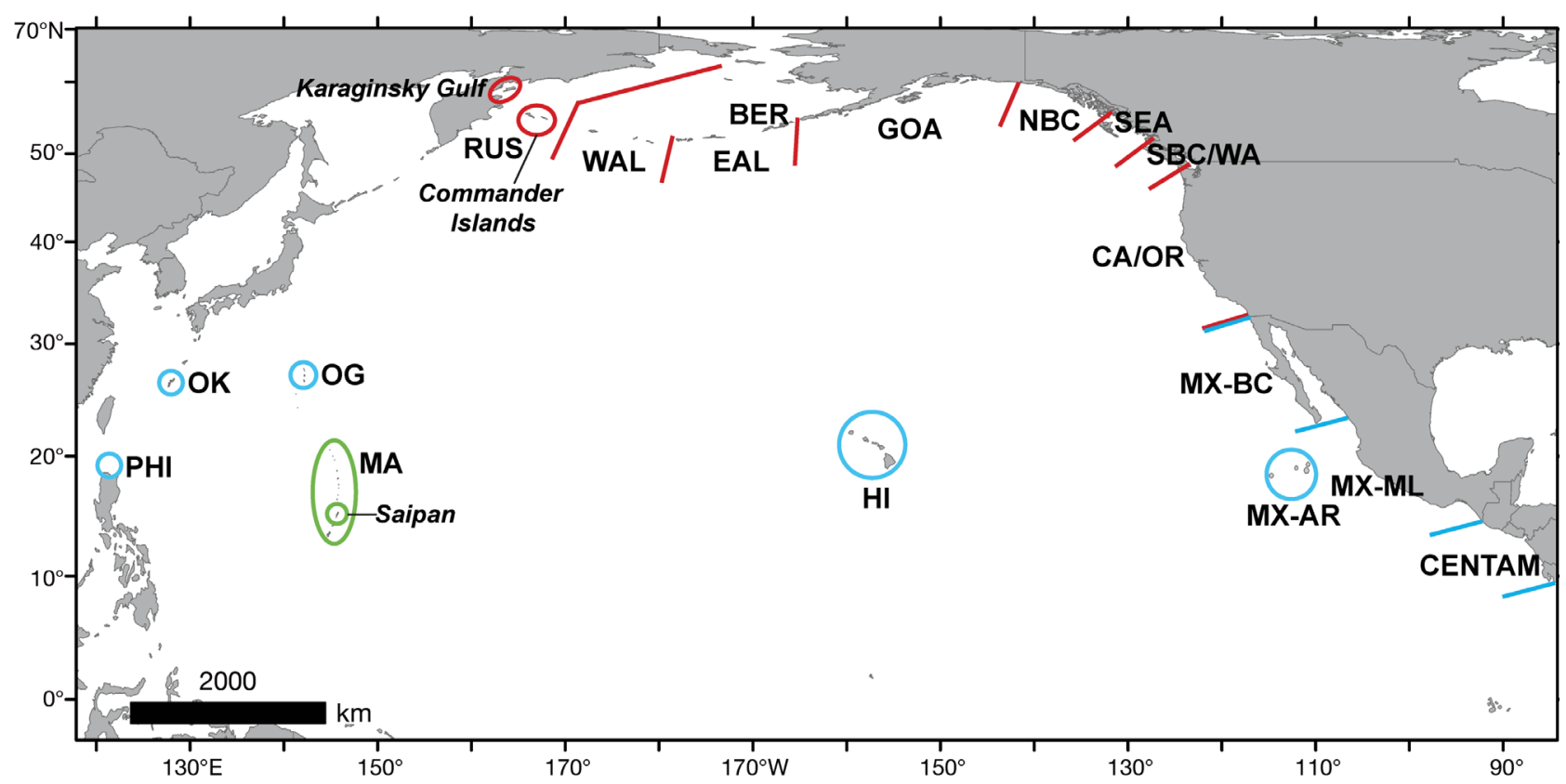

Fig. 1. North Pacific humpback whale summer feeding and winter breeding grounds as defined in the Structure of Populations, Levels of Abundance, and Status of Humpbacks study (SPLASH; Baker et al. 2013) (red circles and lines: feeding areas; blue circles and lines: breeding areas) referenced in Tables 4 \& 5. Feeding grounds (left to right): RUS: Russia; WAL: Western Aleutians; EAL: Eastern Aleutians; BER: Bering; GOA: Gulf of Alaska (stratified into northern and western portions); NBC: northern British Columbia; SEA: Southeast Alaska; SBC/WA: southern British Columbia/Washington; CA/OR: California/Oregon. Breeding grounds (left to right): PHI: Philippines; OK: Okinawa; OG: Ogasawara; MA: Mariana Archipelago (green circles, not included in SPLASH); HI: Hawai'ian Islands; MX-AR: Mexico-Archipelago Revillagigedo; MX-BC: Mexico-Baja California; MX-ML: Mexico-Mainland; CENTAM: Central America 
Results from the SPLASH study also suggested the likelihood of an unknown breeding area in the WNP (Baker et al. 2013, Bettridge et al. 2015). Humpback whales from feeding areas off the Aleutians and in the Bering Sea were not well represented on the known breeding grounds, suggesting that those individuals must be going to one or more unknown winter locations (Barlow et al. 2011). In addition, despite records of individuals migrating between Okinawa and Ogasawara and between Russian feeding grounds and these WNP breeding grounds (Barlow et al. 2011, Bettridge et al. 2015), significant differences in mtDNA haplotype frequencies between Okinawa and Ogasawara and between the Russian feeding grounds and these breeding grounds suggested a missing breeding ground associated with a second breeding population in the WNP (Baker et al. 2013, Bettridge et al. 2015). A comparison of humpback whale photo-identification catalogs from the Russian Far East (1459 individuals; 2004-2016) and from breeding grounds across the North Pacific (20042006; SPLASH), as well as catalogs from WNP breeding grounds off Okinawa (1989-2006) and the northern Philippines (2000-2006) also concluded that there was an undiscovered breeding area in the North Pacific (Titova et al. 2018).

The Mariana Archipelago is located in the WNP and consists of 15 islands that stretch in a northsouth arc along a distance of approximately $890 \mathrm{~km}$ from the northernmost to the southernmost island (see Fig. 2). The Mariana Archipelago is composed of 2 US jurisdictions: the territory of Guam and the Commonwealth of the Northern Mariana Islands (CNMI). While the Mariana Archipelago is documented as a historical wintering area for humpback whales (Rice 1998), there has been no research to confirm that the whales are using the area as a contemporary breeding ground, and data were not collected there during the SPLASH study.

Examination of logbooks from whaling ships in operation during the mid- $19^{\text {th }}$ to early $20^{\text {th }}$ centuries revealed approximately 50 humpback whales were taken during February-May in the waters surrounding the Mariana Archipelago (inside the modern-day Guam/CNMI US exclusive economic zone [EEZ]) (Townsend 1935). The occurrence of humpback whales around the Mariana Archipelago during the late $20^{\text {th }}$ and early $21^{\text {st }}$ centuries is known from incidental sightings (Eldredge 1991, 2003, Darling \& Mori 1993, R. K. Uyeyama unpubl. data), several acoustic detections and a single sighting during a 2007 shipboard cetacean survey (Fulling et al. 2011), passive acoustic recordings from instruments moored to the seafloor off Saipan during 2010-2013 (E. M. Oleson et al. unpubl. data), as well as from a glider that surveyed the waters off the southeastern portion of the Archipelago in October 2014 and March 2015 (H. Klinck et al. unpubl. data). Between 1978 and 2013, there were 19 incidental sighting reports of humpback whales around the southern portion of the Mariana Archipelago, 12 (including 3 with calves) from the islands of Guam, Rota, and Saipan (Eldredge 1991, 2003, Darling \& Mori 1993, R. K. Uyeyama unpubl. data) and 7 (including 2 with calves) around Farallon de Medinilla (R. K. Uyeyama unpubl. data). The Mariana Islands Sea Turtle and Cetacean Survey (MISTCS), a shipboard visual and passive acoustic line-transect survey, was conducted within the US Navy Mariana Islands Range Complex from January-April 2007 (Fulling et al. 2011). There were 11 unique detections of humpback whale song (T. Norris et al. unpubl. data), one of which was localized and led to a sighting of a group of 8 non-calf whales at Marpi Reef, $18 \mathrm{~km}$ north of Saipan (Fulling et al. 2011).

The previously documented presence of 'singers' and calves suggests that humpback whales are using the Mariana Archipelago as a breeding ground, but confirmation was needed that the whales were not simply transiting through the area. Given the location of the Mariana Archipelago in the WNP, humpback whales occurring there are assumed to be part of the WNP population; however, the population identity of these whales had not been established. This study used humpback whale encounters, behavioral observations, and photo-identification and genetic data collected within the southern portion of the Mariana Archipelago to clarify the habitat use and population identity of the whales in this region. Determining the full extent of the range of WNP humpback whales and of links between breeding and feeding areas is necessary to enhance conservation and management actions for this endangered population.

\section{MATERIALS AND METHODS}

\subsection{Surveys and humpback whale encounters}

\subsubsection{Data collection}

Non-systematic surveys for humpback whales were conducted by the Pacific Islands Fisheries Science Center (PIFSC) Cetacean Research Program in waters off the southern Mariana Islands of Saipan, Tinian, and Aguijan (see Fig. 2) during February and March 2015-2018 aboard a 12.2 m sport-fisher with a 
flying bridge and twin-diesel inboard engines. In total, 4-5 observers scanned for whales with unaided eyes, collectively searching $360^{\circ}$ around the vessel. Whales that were sighted were approached for a group-size count, photo-identification, and biopsy sampling. Photographs were taken with telephoto zoom lenses mounted on digital SLR cameras, and an effort was made to photograph both left and right sides of the body and dorsal fin, as well as the ventral surface of the flukes, which is well-established as a photo-identification feature for humpback whales (Katona et al. 1979, Smith et al. 1999, Barlow et al. 2011). Biopsy samples were collected using a Barnett RX-150 crossbow with Ceta-Dart bolts and sterilized stainless steel biopsy tips $(40 \mathrm{~mm}$ long $\times 8 \mathrm{~mm}$ diameter). Additional data collected during each encounter included group location (latitude, longitude) and behavior, as well as the presence of calves and competitive groups. Competitive groups of humpback whales are rarely observed outside of known breeding grounds and consist of a nuclear animal, a female (with or without a calf) or a male, that is surrounded by a male principle escort and other (secondary) escorts that compete, sometimes aggressively, for proximity to the nuclear animal (Tyack \& Whitehead 1983, Clapham et al. 1992). Competitive behaviors include broadside displays, underwater exhalations, head lunges (with throat expansion), physical displacement, charge-strikes, and fluke thrashes (Tyack \& Whitehead 1983, Baker \& Herman 1984). The occurrence of such behaviors was recorded to identify competitive groups. Environmental data (e.g. Beaufort Sea State, swell height) and effort status were recorded regularly as conditions changed. The vessel's track was automatically recorded at 1 min intervals using a handheld GPS.

\subsubsection{Spatial data processing}

For visualization and summary of spatial data, bathymetric data sets of varying resolutions were used, which included high-resolution, multi-beam color-shaded bathymetry for nearshore waters from the Pacific Islands Benthic Habitat Mapping Center (School of Ocean and Earth Science and Technology, University of Hawai'i at Manoa; www.soest.hawaii. edu/pibhmc/cms/data-by-location/cnmi). A Global Multi-Resolution Topography (Marine Geoscience Data System www.marine-geo.org/portals/gmrt; Ryan et al. 2009) custom bathymetric grid encompassing the US EEZs of CNMI and Guam was referenced for offshore areas not covered by the other data sets. All bathymetric data sets were processed using ArcCata$\log 10.3$ (ESRI). The ASCII files were first converted into raster grids, projected in the World Geodetic System (WGS) 1984 Universal Trans Mercator (UTM) Zone $55 \mathrm{~N}$ coordinate system and imported into ArcMap 10.3 (ESRI).

Vessel GPS tracks and encounter locations were also processed in ArcCatalog 10.3, projected in the WGS 1984 UTM Zone 55N coordinate system, and overlaid onto the bathymetric data sets within ArcMap 10.3. Depths of humpback whale encounter and on-effort trackline locations were determined by extracting the depth values from the highest resolution bathymetry data set available. The search effort was then summarized in depth bins of $200 \mathrm{~m}$ intervals. In addition, the distances from the closest shoreline for each encounter location were determined.

\subsection{Photo-identification}

Humpback whale photos collected during the PIFSC effort were compared to those collected during the 2007 MISTCS sighting and then combined to form the first Mariana Archipelago humpback whale photo-identification catalog. Each individual in the catalog is represented by the highest quality photograph available for each available aspect (right and left sides of dorsal fin and ventral fluke surface).

To investigate the migratory connections of Mariana Archipelago humpback whales to other locations in the North Pacific, fluke images from the Mariana Archipelago photo-identification catalog were compared to the SPLASH catalog (www.splashcatalog. org; managed by Cascadia Research Collective), which contains 7931 individuals photographed between 2004 and 2006 at all known North Pacific summer feeding and winter breeding locations (Barlow et al. 2011) (Fig. 1). Additionally, the Mariana Archipelago catalog was shared with organizations studying humpback whales on known breeding and feeding grounds of the WNP for comparison of flukes within the catalog of each organization (Table 1).

\subsection{Genetics}

\subsubsection{DNA extraction, mitochondrial DNA sequencing, and microsatellite genotyping}

Total genomic DNA was extracted from skin biopsy samples using standard proteinase $\mathrm{K}$ digestion and phenol/chloroform methods (Sambrook et al. 1989) 
Table 1. Humpback whale photo-identification catalogs from western North Pacific breeding and feeding grounds that were compared to the Mariana Archipelago catalog of non-calf whale flukes ( $\mathrm{n}=33$ ) collected in 2007 and 2015-2018. Details for each catalog include the location, breeding or feeding ground designation, responsible organization, years of survey effort, and number of individuals (represented by flukes) within each catalog

\begin{tabular}{|c|c|c|c|c|}
\hline Location & $\begin{array}{l}\text { Breeding/ } \\
\text { feeding }\end{array}$ & Organization & Years & $\begin{array}{l}\text { No. of individuals } \\
\text { (flukes) }\end{array}$ \\
\hline Japan: Ogasawara & Breeding & $\begin{array}{c}\text { Ogasawara Marine Center } \\
\text { (OMC) }\end{array}$ & $1987-2014$ & 1696 \\
\hline Japan: Ogasawara & Breeding & $\begin{array}{c}\text { Ogasawara Whale Watching } \\
\text { Association (OWWA) }\end{array}$ & 2014-2018 & 283 \\
\hline Japan: Okinawa & Breeding & $\begin{array}{c}\text { Okinawa Churashima } \\
\text { Research Center (OCRC) }\end{array}$ & 1991-2016 & 1632 \\
\hline $\begin{array}{l}\text { Philippines: Babuyan Islands, } \\
\text { northern Luzon }\end{array}$ & Breeding & BALYENA.ORG (BAL) & 1999-2016 & 234 \\
\hline $\begin{array}{l}\text { Russian Far East: Chukotka and Kamchatka } \\
\text { Peninsulas, Commander and Kuril Islands }\end{array}$ & Feeding & $\begin{array}{c}\text { Russian Cetacean } \\
\text { Habitat Project (RCHP) }\end{array}$ & $1997-2017$ & 1905 \\
\hline
\end{tabular}

as modified by Baker et al. (1994) for small samples. Following Baker et al. (2013), an approximate 800 bp fragment of the mtDNA control region was amplified with the forward primer M13Dlp1.5 and reverse primer Dlp8G (Dalebout et al. 2004) under standard conditions. Also following Baker et al. (2013), control region sequences were edited and trimmed to a $500 \mathrm{bp}$ consensus region in Sequencher v.4.6, and unique haplotypes were aligned with previously published haplotypes downloaded from GenBank ${ }^{\circledR}$.

A standardized set of 10 microsatellite loci was also amplified for each sample using previously published conditions (Baker et al. 2013). These included the following loci: EV14, EV37, EV96 (Valsecchi \& Amos 1996); GATA28, GATA417 (Palsbøll et al. 1997); rw31, rw4-10, rw48 (Waldick et al. 1999); and GT211, GT23, GT575 (Bérubé et al. 2000). Microsatellite loci were individually amplified in $10 \mu \mathrm{l}$ reactions and co-loaded in 2 sets for automated sizing on an ABI 3730xl (Applied Biosystems) DNA analyzer. Using Genemapper v.4.0 (Applied Biosystems), microsatellite alleles were sized and binned, then all peaks were visually inspected.

\subsubsection{Sex and individual identification}

Sex was determined using multiplex polymerase chain reaction with primers P1-5EZ and P2-3EZ to amplify a 443-445 bp region on the $\mathrm{X}$ chromosome (Aasen \& Medrano 1990) and primers Y53-3C and Y53-3D to amplify a 224 bp region on the Y chromosome (Gilson et al. 1998).

The multi-locus genotypes were analyzed using CERVUS v.3.0.3 to identify individual whales (Marshall et al. 1998). As a precaution against false exclu- sion due to allelic dropout and other genotyping errors, initial mismatches of up to 3 loci were allowed (Waits \& Leberg 2000, Waits et al. 2001). For mismatching loci, electropherograms were reviewed and corrected or repeated. A final 'DNA profile' for each sample included 10 microsatellite genotypes, sex, and mtDNA control region sequence or haplotype. The expected probability of identity $\left(P_{\mathrm{ID}}\right)$ for a given number of loci was calculated with GenAlex (Peakall \& Smouse 2006). The $P_{\mathrm{ID}}$ reflects the probability of a pair of individuals sharing a multi-locus genotype by chance, given the frequency of alleles at each microsatellite locus. This probability is typically very low for the 10 microsatellite loci chosen in this study, providing confidence in the identification of individuals (Baker et al. 2013).

For matching of individual genotypes, there is a large 'DNA register' that includes mtDNA haplotypes, sex, and microsatellite genotypes at 10 loci, sufficient for individual identification of 1805 individuals biopsy-sampled in all North Pacific breeding and feeding grounds included in the SPLASH study (Baker et al. 2013). Consequently, microsatellite genotypes can be used to search for recaptures of individuals represented in the DNA register.

\subsubsection{Mitochondrial DNA and population differentiation}

The mtDNA haplotypes of sampled Mariana Archipelago humpback whales were used for comparisons to haplotype frequencies from regions of the North Pacific represented in the SPLASH DNA register. Estimates of haplotype diversity (with standard deviations) and tests of differentiation in mtDNA haplo- 
type frequencies among and between the sampling data sets and the 18 regional strata defined during SPLASH for the North Pacific were conducted with the program Arlequin, and $F_{\mathrm{ST}}$ values were reported (Excoffier \& Lischer 2010). Following Alexander et al. (2016), differences in haplotype diversity were tested using a permutation procedure (Alexander 2017) in the program R (R Core Team 2018).

To better understand the connections between the Mariana Archipelago and feeding grounds in the WNP, tests of differentiation in mtDNA haplotype frequencies were conducted with data available in a published study of humpback whales sampled in the Russian Far East that found evidence of fine-scale differentiation between the Karaginsky Gulf (off the northeastern coast of the Kamchatka Peninsula) and the Commander Islands (Richard et al. 2018). The tests of differentiation included haplotypes of 68 whales from the Karaginsky Gulf and 102 whales from the Commander Islands sampled between 2004 and 2016, including whales sampled during the
SPLASH study (Baker et al. 2013). Although the reported haplotypes from the Russian Far East were standardized to those reported in Baker et al. (2013), the length of the sequence used by Richard et al. (2018) was slightly shorter (472 vs. $500 \mathrm{bp}$ ). This shorter length failed to resolve the difference between 2 common haplotypes in the North Pacific, Aand $\mathrm{A}+$. Consequently, for comparison involving the data reported by Richard et al. (2018), these 2 haplotypes were pooled into a single 'A' haplotype.

\section{RESULTS}

\subsection{Surveys and humpback whale encounters}

During 28 February-8 March 2015, 2-13 March 2016, 11-22 February 2017, and 17-26 February 2018, PIFSC surveys for humpback whales were conducted on 31 days (8 in 2015, 9 in 2016, 6 in 2017, 8 in 2018) (Fig. 2B). Survey effort (183.9 h) was focused
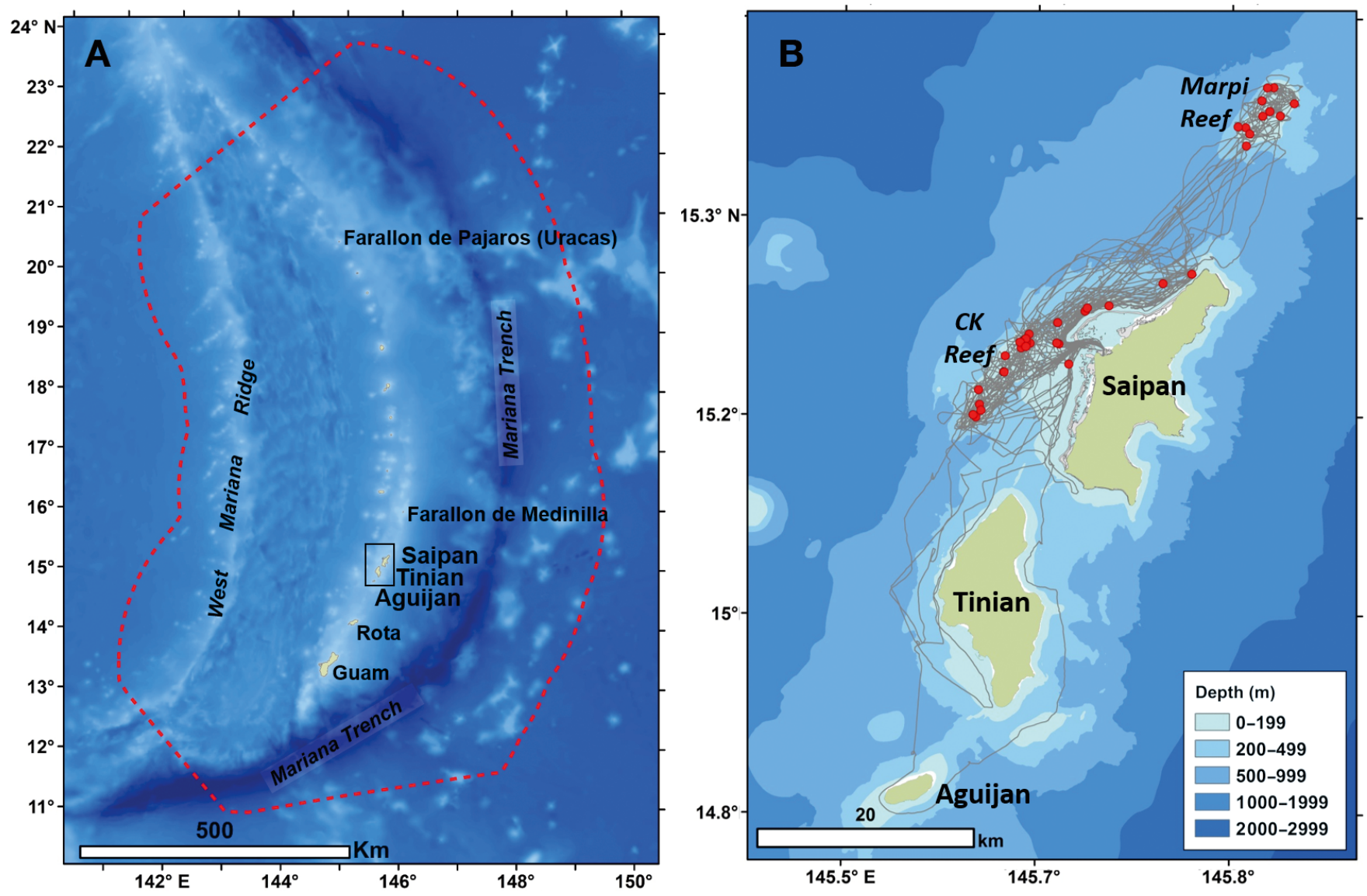

Fig. 2. (A) Mariana Archipelago. Red dashed line: Guam/Commonwealth of the Northern Mariana Islands exclusive economic zone; black rectangle: Pacific Islands Fisheries Science Center's Cetacean Research Program small-boat surveys off Saipan, Tinian, and Aguijan (February-March 2015-2018). (B) Survey tracklines and encounter locations of humpback whales confirmed with photographs (red dots). CK Reef: Chalan Kanoa Reef 
on areas of shallow water, primarily $\leq 200 \mathrm{~m}(62 \%$ of on-effort time). There were 39 encounters with humpback whales (excluding within-day re-sights) during which 17890 photographs and 29 biopsy samples were collected (Table S1 in the Supplement at www.int-res.com/articles/suppl/n041p091_supp. pdf). Most ( $\mathrm{n}=30 ; 77 \%$ ) of the humpback whale encounters were located on 2 offshore reefs (Marpi Reef and Chalan Kanoa [CK] Reef) (Fig. 2B). Most ( $\mathrm{n}=34$; $87 \%$ ) of the encounter location depths were $<100 \mathrm{~m}$ and more than half $(\mathrm{n}=21 ; 54 \%)$ were $<50 \mathrm{~m}$. There were 22 encounters with mother-calf pairs, and most ( $\mathrm{n}=14 ; 64 \%$ ) of these encounters occurred at depths $<50 \mathrm{~m}$. A total of 14 mother-calf pairs and 27 other non-calf whales were observed across all years. All calves were categorized as young-of-the-year (i.e. those born within the current season) based on relative body size; 1 neonate with pale skin color and visible fetal lines (Faria et al. 2013) was encountered in 2016 (Fig. S1). Two females sighted with calves in 2015 were observed again with calves in 2018 (Table 2). One female was observed in 2016 with a calf and was re-sighted in 2017 without a calf. Competitive groups $(n=5)$ were encountered in 2017 and 2018.

\subsection{Photo-identification}

A total of 41 non-calf humpback whales were identified during the PIFSC 2015-2018 surveys. Right side of dorsal fin, left side of dorsal fin, and ventral fluke photographs are available for 40, 38, and 31 individuals, respectively. The 31 PIFSC fluke catalog images were compared to fluke images taken of 4 of the 8 non-calf whales sighted during the 2007 MISTCS encounter on Marpi Reef (Fulling et al. 2011). One MISTCS individual matched a female photographed with her calf in nearshore waters off

Table 2. Humpback whales within the Mariana Archipelago photo-identification catalog re-sighted between years. Information includes photo-identification catalog ID, sex (M: male; F: female; determined by genetics), year first seen, and year(s) re-sighted (letter following year, m: mother)

\begin{tabular}{|cccc|}
\hline Catalog ID & Sex & First year & Re-sight year(s) \\
\hline MIMn-001 & M & 2007 & 2017 \\
MIMn-002 & F & 2007 & $2016(\mathrm{~m})$ \\
MIMn-008 & F & $2015(\mathrm{~m})$ & $2018(\mathrm{~m})$ \\
MIMn-011 & M & 2015 & 2017,2018 \\
MIMn-012 & F & $2015(\mathrm{~m})$ & $2018(\mathrm{~m})$ \\
MIMn-017 & F & $2016(\mathrm{~m})$ & 2017 \\
MIMn-028 & M & 2017 & 2018 \\
\hline
\end{tabular}

the west side of Saipan in 2016, and one matched a male photographed on CK Reef in 2017. PIFSC and MISTCS photographs were combined to form the Mariana Archipelago humpback whale photo-identification catalog of 43 non-calves represented by 33 fluke images. In total, 7 individuals were photographed in the Mariana Archipelago in multiple years (4 females, 3 males) (Table 2 ).

A total of 11 individuals (4 males, 3 females, and 4 whales of unknown sex) from the Mariana Archipelago humpback whale photo-identification catalog were matched by their flukes to individuals from 4 other WNP catalogs from Ogasawara, Okinawa, Philippines, and Russia (Table 3). Three of the individuals were matched to multiple catalogs: 2 were males that had been previously encountered in Ogasawara (one was encountered off Okinawa while the other was encountered in the Philippines and the Commander Islands); the third individual was of unknown sex and had been previously encountered off Okinawa and the Commander Islands. Five other Mariana Archipelago humpback whales (3 females, 2 unknowns) were encountered in Ogasawara. All 3 females were observed with calves in multiple years, and 2 of these whales were with calves in the Mariana Archipelago. The 2 whales of unknown sex were each encountered in Ogasawara and the Mariana Archipelago only once. Lastly, 2 Mariana Archipelago males were encountered off Okinawa, and 1 individual of unknown sex was encountered in the Commander Islands. No matches were found in the Ogasawara Whale Watching Association (OWWA)'s catalog from Ogasawara, and no additional matches were found to any other known breeding or feeding areas covered by the SPLASH catalog.

\subsection{Genetics}

A total of 29 biopsy samples were collected from humpback whales in the Mariana Archipelago during the PIFSC surveys: 4 in 2015, 5 in 2016, 14 in 2017, and 6 in 2018 (Table S1). One sample from 2017 was too small to yield an adequate profile and was not considered further. The remaining 28 samples were of sufficient quality to provide a standard DNA profile, including mtDNA haplotype sequencing, microsatellite genotyping at a minimum of 9 loci, and sex identification. From these, genotype matching identified 24 individuals (14 females, 10 males) collected from 2015-2018. Based on a minimum of 9 microsatellite loci, the $P_{\mathrm{ID}}$ for the genotyped samples ranged from $1.9 \times 10^{-6}$ to $1.9 \times 10^{-10}$, confirming that the probability 


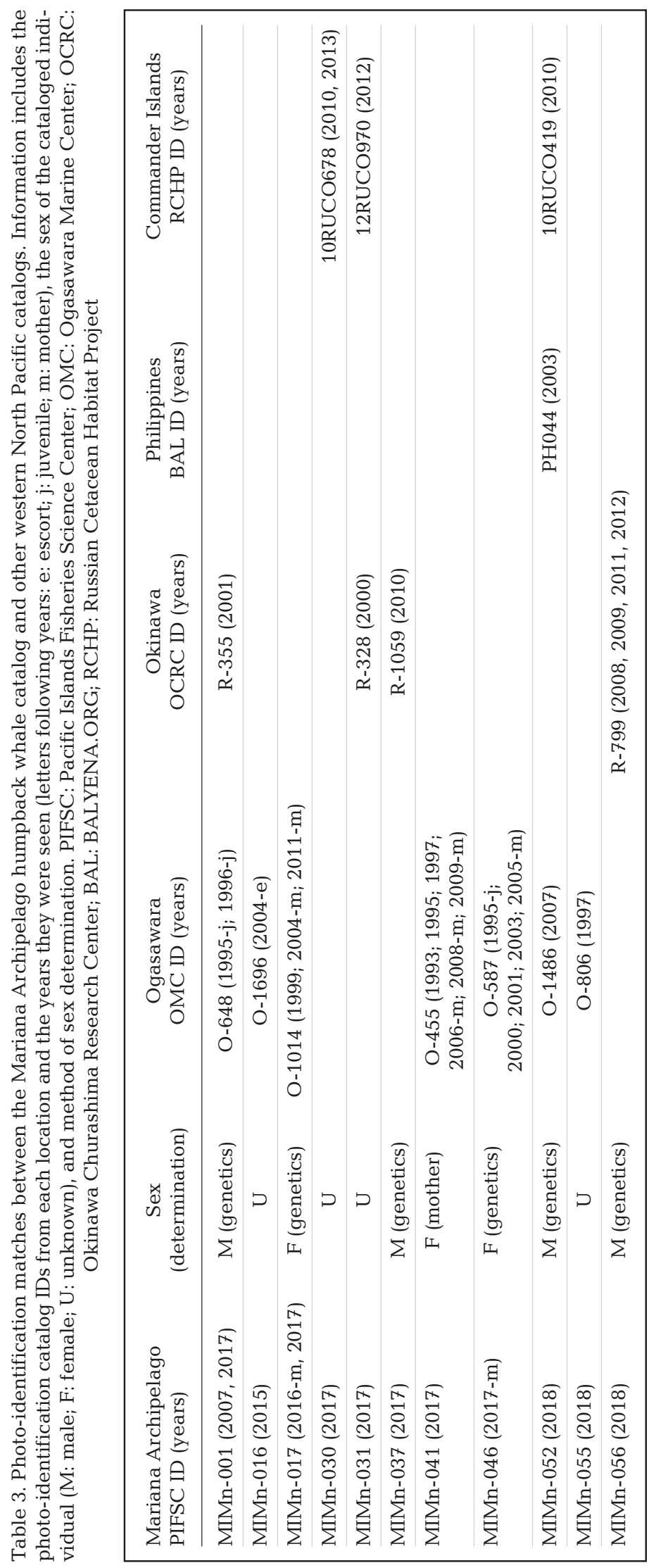

of a match by chance was very low, i.e. unique genotypes represented individual whales, and identical genotypes represented replicate samples of an individual whale.

The 4 recaptures identified by genotype matching revealed 2 between-year matches: a male (MIMn-011) sampled in 2015 and 2017 and a female (MIMn-008) sampled in 2015 and 2018. These recaptures confirmed the photographic matches (Table 2). The remaining 2 recaptures were within-year matches, so no additional between-year matches were identified.

The DNA profiles of the 24 individuals were compared to the SPLASH data set as reported in Baker et al. (2013). This comparison revealed 1 genotype recapture of a female (MIMn-017) sampled in the Mariana Archipelago in 2016 and previously in the Ogasawara Archipelago in 2004. However, this whale was also photographed by the Ogasawara Marine Center (OMC) off Ogasawara in 2004 (Table 4); thus, no additional matches were made from the comparison of DNA profiles.

The mtDNA sequences of the 24 individuals resolved 7 haplotypes from the consensus region of 500 bp: A-, A+, A3, E1, E5, E6, and F2 (Table S2). All haplotypes had been previously described in North Pacific humpback whales (Baker et al. 2013) and so are in the public domain and archived in GenBank (Benson et al. 2013).

Compared to the mtDNA haplotype diversity of humpback whale samples from each of the WNP breeding areas reported previously from the SPLASH program (Baker et al. 2013), the haplotype diversity of Mariana Archipelago humpback whale samples $(\mathrm{h}=0.837, \mathrm{SD}=0.040)$ was similar to those from Ogasawara $(\mathrm{h}=0.865, \mathrm{SD}=0.014$, $p=0.532$ ), but significantly higher than those from Okinawa ( $\mathrm{h}=0.655, \mathrm{SD}=0.059, \mathrm{p}<0.001$ ) and the Philippines $(\mathrm{h}=0.628, \mathrm{SD}=0.143, \mathrm{p}=0.008$ ) (Table S3). For the other North Pacific humpback whale breeding areas sampled during SPLASH, the Mariana Archipelago had a significantly higher haplotype diversity than Hawai'i $(\mathrm{h}=0.718$, $\mathrm{SD}=0.018, \mathrm{p}=0.008$ ) but was similar to those from Mexico and Central America (Table S3).

In pairwise tests of differentiation, the mtDNA haplotype frequencies of Mariana Archipelago samples differed significantly $(\mathrm{p}<0.05)$ from 4 of the 8 breeding grounds (Philippines, Okinawa, Hawai'i, and Central America) and 5 of 10 feeding grounds (Bering, northern Gulf of Alaska, southeast Alaska, northern British Columbia, and 
Table 4. Pairwise tests of differentiation of mtDNA haplotype frequencies between the Mariana Archipelago $(n=24)$ and the 18 regional strata (feeding areas and breeding grounds) defined in the Structure of Populations, Levels of Abundance, and Status of Humpbacks study (SPLASH; Baker et al. 2013) (Fig. 1). Russian samples were combined from 3 primary study areas (Gulf of Anadyr, east Kamchatka Peninsula, and Commander Islands). The Bering study area was off the southwest Alaskan Peninsula and eastern Aleutian Islands north to the Pribilof Islands. Rows in italics indicate low sample numbers for comparisons with the western Aleutians and Philippines. Values in bold are significant at $\mathrm{p}<0.05$

\begin{tabular}{|lrrr|}
\hline Region & \multicolumn{3}{c}{ Mariana Archipelago } \\
& $\mathrm{n}$ & $F_{\mathrm{ST}}(\mathrm{n}=24)$ & $\mathrm{p}$-value \\
& & & \\
& & & \\
Feeding areas & 70 & 0.000 & 0.524 \\
Russia (RUS) & 8 & 0.000 & 0.904 \\
Western Aleutians (WAL) & 114 & 0.034 & $\mathbf{0 . 0 3 4}$ \\
Bering (BER) & 36 & 0.020 & 0.145 \\
Eastern Aleutians (EAL) & 96 & 0.000 & 0.687 \\
Western Gulf of Alaska (WGOA) & 233 & 0.042 & $\mathbf{0 . 0 1 9}$ \\
Northern Gulf of Alaska (NGOA) & 183 & 0.231 & $\mathbf{0 . 0 0 0}$ \\
Southeast Alaska (SEA) & 104 & 0.164 & $<\mathbf{0 . 0 0 1}$ \\
Northern British Columbia (NBC) & 51 & 0.025 & 0.094 \\
Southern BC/Washington (SBC/WA) & 123 & 0.082 & $<\mathbf{0 . 0 0 1}$ \\
California/Oregon (CA/OR) & & & \\
& & & \\
Breeding grounds & 13 & 0.078 & $\mathbf{0 . 0 3 8}$ \\
Philippines (PHI) & 72 & 0.066 & $\mathbf{0 . 0 1 0}$ \\
Okinawa (OK) & 159 & 0.002 & 0.351 \\
Ogasawara (OG) & 227 & 0.074 & $\mathbf{0 . 0 0 4}$ \\
Hawai'i (HI) & 106 & 0.001 & 0.392 \\
Mexico-Archipelago Revillagigedo (MX-AR) & 110 & 0.000 & 0.390 \\
Mexico-Baja California (MX-BC) & 62 & 0.005 & 0.305 \\
Mexico-Mainland (MX-ML) & 36 & 0.097 & $\mathbf{0 . 0 0 3}$ \\
Central America (CENTAM) & & & \\
\hline
\end{tabular}

Table 5. Pairwise tests of differentiation of mtDNA haplotype frequencies between feeding grounds in the Russian Far East and breeding grounds as defined in the Structure of Populations, Levels of Abundance, and Status of Humpbacks study (SPLASH; Baker et al. 2013), with the inclusion of the Mariana Archipelago (Fig. 1). Note that haplotypes A- and A+ have been pooled to allow comparison of data from Baker et al. (2013) and Richard et al. (2018). Mexico-AR: Archipelago Revillagigedo; Mexico-BC: Baja California; Mexico-ML: Mainland. Values in bold are significant at $\mathrm{p}<0.05$

\begin{tabular}{|c|c|c|c|c|}
\hline \multirow[t]{2}{*}{$\begin{array}{c}\text { Breeding } \\
\text { ground }\end{array}$} & \multicolumn{2}{|c|}{$\begin{array}{l}\text { Karaginsky Gulf } \\
\quad(\mathrm{n}=68)\end{array}$} & \multicolumn{2}{|c|}{$\begin{array}{c}\text { Commander Islands } \\
(\mathrm{n}=102)\end{array}$} \\
\hline & $F_{\mathrm{ST}}$ & $\mathrm{p}$-value & $F_{\mathrm{ST}}$ & p-value \\
\hline Philippines & 0.016 & 0.225 & 0.164 & $<0.001$ \\
\hline Okinawa & 0.024 & 0.032 & 0.153 & $<0.001$ \\
\hline Ogasawara & 0.083 & $<0.001$ & 0.042 & $<0.001$ \\
\hline Mariana Archipelago & 0.114 & 0.009 & 0.000 & 0.679 \\
\hline Hawai'i & 0.429 & $<0.001$ & 0.090 & $<0.001$ \\
\hline Mexico-AR & 0.144 & $<0.001$ & 0.007 & 0.103 \\
\hline Mexico-BC & 0.125 & $<0.001$ & 0.012 & 0.038 \\
\hline Mexico-ML & 0.135 & $<0.001$ & 0.007 & 0.139 \\
\hline Central America & 0.123 & $<0.001$ & 0.168 & $<0.001$ \\
\hline
\end{tabular}

California/Oregon) sampled in SPLASH (Table 4, Fig. 1). In the WNP, there was no significant difference in mtDNA haplotype frequencies of Mariana Archipelago samples and those from feeding grounds off Russia (combined during SPLASH) and the western Aleutians (where sample size was low) or those from the Ogasawara breeding ground.

After combining the A+ and A- haplotypes, tests of differentiation were conducted between the North Pacific breeding grounds and both the Karaginsky Gulf and the Commander Islands feeding grounds. Results showed strong differentiation of the Karaginsky Gulf from the Mariana Archipelago and all other breeding grounds, except the Philippines (represented by a small sample size) (Table 5 , Figs. 1 \& S2). The Commander Islands showed significant differentiation from all other breeding grounds of the WNP, but showed near identity (i.e. $F_{\mathrm{ST}}=0.000$ ) with the Mariana Archipelago.

\section{DISCUSSION}

This study provides evidence that the Mariana Archipelago, located in the WNP, serves as a breeding ground for humpback whales. Competitive groups and very young calves, including a neonate, were observed in multiple years off Saipan, suggesting that humpback whales are mating and calving there. All but 4 encounter locations had water depths $<200 \mathrm{~m}$, which is characteristic of humpback whale breeding habitat (Frankel et al. 1995, Craig \& Herman 2000), within which mothers and calves are typically found in depths of $50 \mathrm{~m}$ or less (Ersts \& Rosenbaum 2003, Rasmussen et al. 2012). During this study, more than half of the encounter locations with mother-calf pairs were inside of the $50 \mathrm{~m}$ depth contour. Non-calf individuals demonstrated site fidelity by returning to Saipan in multiple years, including females associated with calves in one or more years.

Although the SPLASH study focused on all of the known breeding and feeding grounds of humpback whales in the North 
Pacific, results suggested that there may be an unknown breeding area in the WNP (Baker et al. 2013, Bettridge et al. 2015). In addition, significant differentiation in mtDNA haplotype frequencies between Ogasawara and both Okinawa $\left(F_{\mathrm{ST}}=0.059, \mathrm{p}<0.001\right)$ and the Philippines $\left(F_{\mathrm{ST}}=0.068, \mathrm{p}<0.01\right)$ (Baker et al. 2013) led to the conclusion that there are likely 2 WNP breeding populations that overlap or mix in Ogasawara; one that winters in Okinawa and the Philippines and a second that winters in an unknown area(s) (Bettridge et al. 2015).

Photo-identification and genetic data suggest that Mariana Archipelago humpback whales are part of the WNP population. One-third $(\mathrm{n}=11)$ of the Mariana Archipelago individuals with fluke images were photographed on known WNP humpback whale breeding (Ogasawara, Okinawa, Philippines) and feeding (Commander Islands) grounds. Most of the matched individuals $(n=7)$ were seen off Ogasawara, which is just north of the Mariana Archipelago and may serve as a migratory corridor for the whales on their way north to feeding grounds. The low differentiation in mtDNA haplotype frequencies $\left(F_{\mathrm{ST}}=\right.$ $0.002, \mathrm{p}=0.351$ ) and similar haplotype diversity of the Mariana Archipelago $(\mathrm{h}=0.837, \mathrm{SD}=0.040)$ and Ogasawara $(\mathrm{h}=0.865, \mathrm{SD}=0.014, \mathrm{p}=0.532)$ suggest there is high interchange between locations. The haplotype diversity in Mariana Archipelago humpback whales was significantly higher than the SPLASH samples from Okinawa $(\mathrm{h}=0.655, \mathrm{SD}=$ 0.059, $\mathrm{p}<0.001)$ and the Philippines $(\mathrm{h}=0.628, \mathrm{SD}=$ $0.143, p=0.008$ ), and there is significant differentiation in humpback whale mtDNA haplotype frequencies from the Mariana Archipelago and both Okinawa $\left(F_{\mathrm{ST}}=0.066, \mathrm{p}<0.01 ; \mathrm{h}=0.655, \mathrm{SD}=0.059, \mathrm{p}<\right.$ $0.001)$ and the Philippines $\left(F_{\mathrm{ST}}=0.078, \mathrm{p}<0.05 ; \mathrm{h}=\right.$ $0.628, \mathrm{SD}=0.143, \mathrm{p}=0.008$ ), as was found with Ogasawara and the breeding grounds off Okinawa and the Philippines during the SPLASH study (Baker et al. 2013). This further supports the suggestion that there are 2 WNP breeding populations, but more genetic data from the Mariana Archipelago and the Philippines are needed.

Although there were documented movements of individuals between all of the WNP breeding areas, including the Mariana Archipelago, it is possible that some were temporary explorations that were reproductively unsuccessful and had no effect on gene flow (Slatkin 1987, Baker et al. 2013). A small number of humpback whales have moved between Hawai'i and the WNP breeding areas in different years (multiple years in some cases; Darling \& Cerchio 1993, Salden et al. 1999, Calambokidis et al. 2001); however, Baker et al. (2013) found strong genetic differentiation between these breeding regions. In addition, the haplotype diversity in Mariana Archipelago humpback whales was significantly higher than the SPLASH samples from Hawai'i, and there was strong differentiation in the mtDNA haplotype frequencies between these breeding locations.

The comparison of Mariana Archipelago mtDNA haplotype frequencies to other North Pacific breeding grounds resulted in low $F_{\mathrm{ST}}$ values for all 3 Mexican breeding grounds. Baker et al. (2013) found significant differentiation between the mtDNA haplotype frequencies of the Mexican breeding grounds and all other North Pacific breeding grounds including Ogasawara. There have been no documented movements between Mexican and WNP breeding grounds, but Titova et al. (2018) found 11 photo-identification matches between the Commander Islands feeding grounds and the 3 Mexican breeding grounds. Clark \& Clapham (2004) suggested that mating may occur in small numbers on feeding grounds or during migration based on the combined evidence from recordings made of continual singing on a humpback whale feeding ground off Cape Cod, Massachusetts, in late May to early June 2000 and that of aseasonal conceptions (i.e. outliers in expected foetal lengths) from whaling data. Interchange on the Commander Islands feeding ground or during migration could explain some of the connection between the Mariana Archipelago and the Mexican breeding grounds, but unlikely all. A larger sample size from the Mariana Archipelago may help elucidate this question.

For migratory baleen whales, maternal fidelity to breeding and feeding grounds is thought to influence the observed differences in mtDNA haplotype frequencies among those areas (Baker et al. 2013). Similarities in haplotype frequencies between breeding and feeding areas in the SPLASH study reflected known migratory connections (Baker et al. 2013). There is no distinction between the mtDNA haplotype frequencies of the humpback whales sampled in the Mariana Archipelago and Commander Islands $\left(F_{\mathrm{ST}}=0.000\right)$ and a significant differentiation between the Mariana Archipelago and Karaginsky Gulf $\left(F_{\mathrm{ST}}=\right.$ $0.114, p<0.01)$. Thus, genetic comparisons of the Mariana Archipelago with the recent surveys of feeding grounds from the Russian Far East support a close (although not exclusive) connection with the Commander Islands and an abrupt boundary with feeding grounds from the east coast of the Kamchatka Peninsula (i.e. Karaginsky Gulf) (Richard et al. 2018). There are weaker connections between Ogasawara and both the Commander Islands $\left(F_{\mathrm{ST}}=\right.$ 
$0.042, \mathrm{p}<0.001)$ and Karaginsky Gulf $\left(F_{\mathrm{ST}}=0.083\right.$, $\mathrm{p}<0.001$ ). During the SPLASH study, photo-identification matches were made between Ogasawara and several North Pacific feeding grounds, including the Karaginsky Gulf, Commander Islands, Aleutian Island/Bering Sea area, and the Gulf of Alaska (Barlow et al. 2011); however, comparisons of mtDNA haplotype frequencies from Ogasawara with all North Pacific feeding areas showed strong differentiation (Baker et al. 2013). No photo-identification matches were found between the Mariana Archipelago humpback whale catalog and any of the feeding grounds within the SPLASH catalog; however, comparisons of mtDNA haplotype frequencies suggest strong connections between the Mariana Archipelago and the pooled Russia sample locations $\left(F_{\mathrm{ST}}=\right.$ $0.000)$, western Gulf of Alaska $\left(F_{\mathrm{ST}}=0.000\right)$, and western Aleutians $\left(F_{\mathrm{ST}}=0.000\right)$ and slightly weaker connections to the eastern Aleutians $\left(F_{\mathrm{ST}}=0.020\right)$ and southern British Columbia/Washington $\left(F_{\mathrm{ST}}=0.025\right)$. Additional photo and biopsy effort in these regions, where sample sizes were low, could better establish links to the Mariana Archipelago.

While the spatial and temporal extent of the present study was narrow and the number of individual whales encountered was small, it is clear that the waters off Saipan in the Mariana Archipelago are part of a breeding ground for WNP humpback whales. The Mariana Archipelago may represent a 'missing' breeding area that had been hypothesized in previous studies, even though the number of individuals encountered during this study was small and does not represent the total number of 'missing' individuals from the Russian, eastern Aleutian, and Bering Sea feeding grounds (Barlow et al. 2011, Titova et al. 2018). Future surveys are needed of other shallow water ( $\leq 200 \mathrm{~m}$ depth) locations within the Mariana Archipelago, including those where humpback whales have previously been seen (e.g. Guam, Rota, Farallon de Medinilla, Pagan) to determine the spatial extent of the Mariana Archipelago breeding ground and how many whales it supports.

Thomas et al. (2016) assessed the status of baleen whales worldwide and concluded that humpback whales in the WNP had the 'greatest need of assessment'. SPLASH abundance estimates for humpback whales from the WNP were low (approximately 1000 ind.) and below historical levels based on back-calculating abundance from the number of whales taken in the region (Muto et al. 2018). In addition, reports provided to the International Whaling Commission indicated an increase in the number of humpback whales in the WNP taken incidentally in fisheries of Japan, where products from these whales can be sold commercially (Baker et al. 2000, Thomas et al. 2016). Other potential threats to WNP humpback whales include vessel strikes, vessel noise, and naval sonar (Miller et al. 2000, Sivle et al. 2016, Thomas et al. 2016, Tsujii et al. 2018).

Given their endangered status, knowledge about the breeding grounds and population identity of WNP humpback whales is critical to planning for their recovery. The Mariana Archipelago should be considered in continued efforts to assess the population status of humpback whales in the WNP, as well as in plans to recover this endangered population. This is particularly important if it is confirmed that the humpback whales in the Mariana Archipelago are part of a separate WNP breeding population.

Acknowledgements. Research in the Mariana Archipelago was conducted under the National Marine Fisheries Service (NMFS) permit 15240 and CNMI Department of Fish and Wildlife (DFW) license nos. 03086-2015, 03292-2016, 0356417, and 03752-18 issued to PIFSC. Funding was provided by Commander, US Pacific Fleet, PIFSC, and NMFS. In the Philippines, funding was provided by World Wildlife FundPhilippines, Ocean Park Conservation Foundation-Hong Kong, Whale and Dolphin Conservation Society, Whale Trust, Department of Environment and Natural ResourcesIntegrated Coastal Resources Management Project (DENRICRMP), The Rufford Foundation, and Conservation Sew Mates. In the Russian Pacific, funding was provided by the Russian Foundation for Basic Research (grant no. 18-0400462), the Pew Marine Fellowship, and the Russian Geographical Society. We thank the following individuals and organizations that provided logistical and research support — in the Mariana Archipelago: Mike Trianni, Steve McKagan, Eric Cruz, Erik Norris, Sarah Mallette, Jessica Chen, Laura Morse, Alyson Azzara, Jim Cotton, Cornelia Oedekoven, the CNMI DFW, the owner, captain, and crew of 'Sea Hunter', and the staff of Hyatt Regency Saipan; in Ogasawara: all photo contributors to the OWWA, including captains, tour guides, and tourists; in Okinawa: the captains of the research vessels, Kiyoteru Toyama, Yukinobu Taira, Hisao Miyahira, Kiyohide Miyahira, Yukifumi Miyamura, Keiko Tamura, Sachie Ozawa, Naoto Higashi, Senzo Uchida, and all other humpback whale research staff of the Okinawa Churashima Foundation and Okinawa Churaumi Aquarium, Japan; in the Philippines: Shotaro Nakagun, Elson Aca, Darius Macusi, A. G. Saño, Ivan Sarenas, Dexter Bongo, and all other volunteers and researchers; in the Russian Pacific: Erich Hoyt, Alexander Burdin, Ivan Fedutin, and the staff of the Commander Biosphere Reserve. We thank Cascadia Research Collective for access to the online SPLASH catalog. We also thank Robert Brownell, Ann Allen, and 3 anonymous reviewers whose thoughtful input improved the manuscript.

\section{LITERATURE CITED}

Aasen E, Medrano JF (1990) Amplification of the Zfy and Zfx genes for sex identification in humans, cattle, sheep and goats. Nat Biotechnol 8:1279-1281 
Acebes JMV, Darling DJ, Yamaguchi M (2007) Status and distribution of humpback whales (Megaptera novaeangliae) in northern Luzon, Philippines. J Cetacean Res Manag 9:37-43

Alexander A, Steel D, Hoekzema K, Mesnick SL and others (2016) What influences the worldwide genetic structure of sperm whales (Physeter macrocephalus)? Mol Ecol 25: 2754-2772

Alexander A (2017) genetic_diversity_diffs v1.0.6. https:// github.com/laninsky/genetic_diversity_diffs

Baker CS, Herman LM (1984) Aggressive behavior between humpback whales (Megaptera novaeangliae) wintering in Hawai'ian waters. Can J Zool 62:1922-1937

Baker CS, Slade RW, Bannister JL, Abernethy RB and others (1994) Hierarchical structure of mitochondrial DNA gene flow among humpback whales, Megaptera novaeangliae, world wide. Mol Ecol 3:313-327

Baker CS, Lento GL, Cipriano F, Palumbi SR (2000) Predicted decline of protected whales based on molecular genetic monitoring of Japanese and Korean markets. Proc R Soc B 267:1191-1199

Baker CS, Steel D, Calambokidis J, Falcone EA and others (2013) Strong maternal fidelity and natal philopatry shape genetic structure in North Pacific humpback whales. Mar Ecol Prog Ser 494:291-306

Barlow J, Calambokidis J, Falcone EA, Baker CS and others (2011) Humpback whale abundance in the North Pacific estimated by photographic capture-recapture with bias correction from simulation studies. Mar Mamm Sci 27: 793-818

Benson DA, Cavanaugh M, Clark K, Karsch-Mizrachi I, Lipman DJ, Ostell J, Sayers EW (2013) GenBank. Nucleic Acids Res 41:D36-D42

Bérubé M, Jørgensen H, McEwing R, Palsbøll PJ (2000) Polymorphic di-nucleotide microsatellite loci isolated from the humpback whale, Megaptera novaeangliae. Mol Ecol 9: 2181-2183

Bettridge S, Baker CS, Barlow J, Clapham PJ and others (2015) Status review of the humpback whale (Megaptera novaeangliae) under the Endangered Species Act. NOAA Tech Memo NMFS-SWFSC-540

Calambokidis J, Steiger GH, Straley JM, Herman LM and others (2001) Movements and population structure of humpback whales in the North Pacific. Mar Mamm Sci 17:769-794

* Clapham PJ, Palsbøll PJ, Matilla DK, Vasquez O (1992) Composition and dynamics of humpback whale competitive groups in the West Indies. Behaviour 122:182-194

Clark CW, Clapham PJ (2004) Acoustic monitoring on a humpback whale (Megaptera novaeangliae) feeding ground shows continual singing into late spring. Proc R Soc B 271:1051-1057

Craig AS, Herman LM (2000) Habitat preferences of female humpback whales Megaptera novaeangliae in Hawai'ian waters are associated with reproductive status. Mar Ecol Prog Ser 193:209-216

Dalebout ML, Baker CS, Mead JG, Cockcroft VG, Yamada TK (2004) A comprehensive and validated molecular taxonomy of beaked whales, Family Ziphiidae. J Hered 95: 459-473

Darling JD, Cerchio S (1993) Movement of a humpback whale (Megaptera novaeangliae) between Japan and Hawai'i. Mar Mamm Sci 9:84-89

Darling JD, Mori K (1993) Recent observations of humpback whales (Megaptera novaeangliae) in Japanese waters off Ogasawara and Okinawa. Can J Zool 71: 325-333

*Darling JD, Calambokidis J, Balcomb KC, Bloedel P and others (1996) Movement of a humpback whale (Megaptera novaeangliae) from Japan to British Coumbia and return. Mar Mamm Sci 12:281-287

Eldredge LG (1991) Annotated checklist of the marine mammals of Micronesia. Micronesica 24:217-230

Eldredge LG (2003) The marine reptiles and mammals of Guam. Micronesica 35-36:653-660

Ersts PJ, Rosenbaum HC (2003) Habitat preference reflects social organization of humpback whales (Megaptera novaeangliae) on a wintering ground. J Zool (Lond) 260: 337-345

Excoffier L, Lischer HEL (2010) Arlequin suite ver 3.5: a new series of programs to perform population genetics analyses under Linux and Windows. Mol Ecol Resour 10: 564-567

Faria MA, DeWeerdt J, Pace F, Mayer FX (2013) Observation of a humpback whale (Megaptera novaeangliae) birth in the coastal waters of Sainte Marie Island, Madagascar. Aquat Mamm 39:296-305

Frankel AS, Clark CW, Herman LM, Gabriele CM (1995) Spatial distribution, habitat utilization, and social interactions of humpback whales, Megaptera novaeangliae, off Hawai'i, determined using acoustic and visual techniques. Can J Zool 73:1134-1136

Fulling GL, Thorson PH, Rivers J (2011) Distribution and abundance estimates for cetaceans in the waters off Guam and the Commonwealth of the Northern Mariana Islands. Pac Sci 65:321-343

Gilson A, Syvanen M, Levine K, Banks J (1998) Deer gender determination by polymerase chain reaction: validation study and application to tissues, bloodstains, and hair forensic samples in California. Calif Fish Game 84: 159-169

Katona S, Baxter B, Brazier O, Kraus S, Perkins J, Whitehead $\mathrm{H}$ (1979) Identification of humpback whales by fluke photographs. In: Winn HE, Olla BL (eds) Behavior of marine animals. Springer, Boston, MA, p 33-44

Marshall TC, Slate J, Kruuk LE, Pemberton JM (1998) Statistical confidence for likelihood-based paternity inference in natural populations. Mol Ecol 7:639-655

Miller PJO, Biassoni N, Samuels A, Tyack PL (2000) Whale songs lengthen in response to sonar. Nature 405:903

Muto MM, Helker VT, Angliss RP, Allen BA and others (2018) Alaska marine mammal stock assessments, 2017. NOAA Tech Memo NMFS-AFSC-378

Nishiwaki M (1966) Distribution and migration of the larger cetaceans in the North Pacific as shown by Japanese whaling results. In: Norris KS (ed) Whales, dolphins and porpoises. University of California Press, Berkeley, CA, p 171-191

NOAA (2016) Endangered and threatened species; identification of 14 distinct population segments of the humpback whale (Megaptera novaeangliae) and revision of species-wide listing. Fed Regist 81:62260-62320

Ohsumi S, Masaki Y (1975) Japanese whale marking in the North Pacific, 1963-1972. Bull Far Seas Fish Res Lab 12: $171-219$

Omura H, Ohsumi S (1964) A review of Japanese whale marking in the North Pacific to the end of 1962, with some information on marking in the Antarctic. Nor HvalfangstTid 4:90-112

Palsbøll PJ, Bérubé M, Larsen AH, Jørgensen H (1997) 
Primers for the amplification of tri- and tetramer microsatellite loci in baleen whales. Mol Ecol 6:893-895

Peakall R, Smouse PE (2006) GenAlEx 6: genetic analysis in Excel. Population genetic software for teaching and research. Mol Ecol Notes 6:288-295

R Core Team (2018) R: a language and environment for statistical computing. R Foundation for Statistical Computing, Vienna

Rasmussen K, Calambokidis J, Steiger GH (2012) Distribution and migratory destinations of humpback whales off the Pacific coast of Central America during the boreal winters of 1996-2003. Mar Mamm Sci 28:E267-E279

Rice DW (1998) Marine mammals of the world: systematics and distribution. Soc Mar Mamm Spec Publ No. 4. Allen Press, Lawrence, KS

Richard G, Titova OG, Fedutin ID, Steel D and others (2018) Cultural transmission of fine-scale fidelity to feeding sites may shape humpback whale genetic diversity in Russian Pacific waters. J Hered 109:724-734

Ryan WBF, Carbotte SM, Coplan JO, O'Hara S and others (2009) Global multi-resolution topography synthesis. Geochem Geophys Geosyst 10:2009Q03014

Salden DR, Herman LM, Yamaguchi M, Sato F (1999) Multiple visits of individual humpback whales (Megaptera novaeangliae) between the Hawai'ian and Japanese winter grounds. Can J Zool 77:504-508

Sambrook J, Fritsch EF, Maniatis T (1989) Molecular cloning: a laboratory manual, 2nd edn. Cold Spring Harbor Laboratory Press, Cold Spring Harbor, NY

Silberg J, Acebes N, Burdin JMV, Mamaev AM, Dolan EG, Layusa KC, Aca CA (2013) New insight into migration patterns of western North Pacific humpback whales between Babuyan Islands, Philippines and the Commander Islands, Russia. J Cetacean Res Manag 13:53-57

Sivle LD, Wensveen PJ, Kvadsheim PH, Lam FPA and others (2016) Naval sonar disrupts foraging in humpback whales. Mar Ecol Prog Ser 562:211-220

Editorial responsibility: Jeremy Kiszka, North Miami, Florida, USA
Slatkin M (1987) Gene flow and the geographic structure of natural populations. Science 236:787-792

Smith TD, Allen J, Clapham PJ, Hammond PS and others (1999) An ocean-basin-wide mark-recapture study of the North Atlantic humpback whale (Megaptera novaeangliae). Mar Mamm Sci 15:1-32

Thomas PO, Reeves RR, Brownell RL Jr (2016) Status of the world's baleen whales. Mar Mamm Sci 32:682-734

* Titova OV, Filatova OA, Fedutin ID, Ovsyanikova EN and others (2018) Photo-identification matches of humpback whales (Megaptera novaeangliae) from feeding areas in Russian Far East seas and breeding grounds in the North Pacific. Mar Mamm Sci 34:100-112

Townsend CH (1935) The distribution of certain whales as shown by logbook records of American whaleships. Zoologica 191:1-50

* Tsujii K, Akamatsu T, Okamoto R, Mori K, Mitani Y, Umeda N (2018) Change in singing behavior of humpback whales caused by shipping noise. PLOS ONE 13:e0204112

* Tyack P, Whitehead H (1983) Male competition in large groups of wintering humpback whales. Behaviour 83: 132-154

Valsecchi E, Amos W (1996) Microsatellite markers for the study of cetacean populations. Mol Ecol 5:151-156

*Waits JL, Leberg PL (2000) Biases associated with population estimation using molecular tagging. Anim Conserv 3:191-199

Waits LP, Luikart G, Taberlet P (2001) Estimating the probability of identity among genotypes in natural populations: cautions and guidelines. Mol Ecol 10:249-256

Waldick RC, Brown MW, White BN (1999) Characterization and isolation of microsatellite loci from the endangered North Atlantic right whale. Mol Ecol 8:1763-1765

Witteveen BH, Straley JM, von Ziegesar O, Steel D, Baker CS (2004) Abundance and mtDNA differentiation of humpback whales (Megaptera novaeangliae) in the Shumagin Islands, Alaska. Can J Zool 82:1352-1359

Submitted: June 17, 2019; Accepted: November 12, 2019 Proofs received from author(s): January 19, 2020 